\title{
Effects of human-animal relationship on animal productivity and welfare
}

\author{
Daniel Mota-Rojas (iD . Donald Maurice Broom (iD . Agustín Orihuela (iD. Antonio Velarde (iD.
}

Fabio Napolitano (D) María Alonso-Spilsbury iD

\section{Mota-Rojas • M Alonso-Spilsbury}

Neurophysiology, behaviour and assessment of welfare in domestic animals. Department of Animal Production and Agriculture, Universidad Autónoma Metropolitana (UAM), Mexico City, Mexico.

\section{DM Broom}

Department of Veterinary Medicine, University of Cambridge, Cambridge, United Kingdom.

A Orihuela (Corresponding author)

Facultad de Ciencias Agropecuarias, Universidad Autónoma del Estado de Morelos, Cuernavaca, Morelos, México.
A Velarde

Institute of Agrifood Research and Technology - IRTA, Animal Welfare Program, Veinat Sies S-N, Monells 17121, Spain.

\section{F Napolitano}

Scuola di Scienze Agrarie, Forestali, Alimentari ed Ambientali, Università degli Studi della Basilicata, 85100 Potenza, Italy.

email: agustin.orihuela.trujillo@gmail.com

\begin{abstract}
This is a literature review of the effects of humans' relationships with farm animals on animal productivity and welfare, including the following topics: definition of the concept and description of different tests that have been developed to measure human-animal relationship (HAR). Temperament and tameness, which have been considered as farm animal characteristics that are important in HAR, as are stockperson attitudes. Some international farm animal welfare protocols are also described, together with negative and positive stimuli that affect farm animal welfare and productivity. In addition to some factors affecting the quality of HAR. We conclude that even with improved precision farming and automation: a) a good HAR is still fundamental to improve farm animal welfare with associated health and production benefits and $b$ ) with the numerous tests assessing fear of humans, many are not commercially applicable.
\end{abstract}

Keywords: fear, sensitive period, tameness, wellbeing

\section{Introduction}

According to Waiblinger et al (2006) and Ellingsen et al (2014), human-animal relationships (HAR) can be defined as "the degree of relation or distance that exists between an animal and a human being, perceived, developed and expressed through their mutual behaviour". To create a relation between any two individuals, entails on the one hand, repeated encounters and, on the other, certain cognitive abilities; that is, the capacities that allow individuals to associate the positive or negative emotional content of interactions with another individual, and then recall it when predicting future encounters (Sankey et al 2010).

Farm animals, may perceive interaction with humans as: a) negative, when they fear people, avoiding contact with them; b) neutral, when the fear level is low but animals still avoid contact; and c) positive, when fear is absent, and animals allow physical (Claxton 2011; des Roches et al 2016). Handling that includes abrupt movements, pushing and the use of prods, shouts and kicks is considered negative, while handling characterised by slow movements, whispers and petting have positive effects on animals (Ellingsen et al 2014). Non-aggressive controlling interactions, such as gentle stick use, gentle handling and instructive talking, are considered neutral (Waiblinger et al 2002). Classic conditioning processes can occur when farm animals associate either negative or positive handling with specific humans responsible for their care (Rushen et al 1999ab) and may also lead them to generalise their responses to other people (Waiblinger et al 2006).

The use of positive reinforcements, like feeding or tactile contact, often fosters learning in farm animals (Rochais et al 2014) and may stimulate physiological reactions that can be interpreted as "anti-stress effects" (Lürzel et al 2015). This is one of the means of improving the quality of HAR.

The objective of this literature review is to show the effects of humans' relationships with farm animals on animal productivity and welfare. 


\section{Measures of HAR}

Evaluating the quality of HAR is an important means of improving animal welfare. This process must consider the behaviour of the animals towards stockpersons as well as the behaviour of the stockpersons towards the animals. HAR is considered in international animal welfare protocols for monitoring welfare in production units. For example, the Welfare Quality ${ }^{\circledR}$ protocols (WQ ${ }^{\circledR} 2009 \mathrm{abc}$; des Roches et al 2016), as well as others included in the Animal Welfare Indicators project (AWIN) (Caroprese et al 2016).

Assessing the quality of HAR requires the gathering of evidence that is: a) valid (i.e., reflects what actually occurs); b) reliable (i.e., the tendency to give consistent results with repeated measurement); and c) viable (in terms of time, financial resources and safety) (Napolitano et al 2011; des Roches et al 2016).

Important human factors to be considered during this assessment are stockpersons' attitudes, personality, knowledge, experience and degree of work satisfaction. The attitude towards any kind of animal will affect the quality of interaction and the type of handling. Attitudes during animal handling have been classified as: a) tranquil or friendly; b) dominant; c) impatient; and d) aggressive (Waiblinger et al 2006).

Figure 1 shows the model proposed by Hemsworth and Coleman (1998) to describe the effect of HAR on animal productivity and welfare, as well as the reciprocal relationship between the attitude of a person who handles farm animals and the animal's behavioural response towards him. Within this topic Welp et al (2004) found that dairy cows show greater vigilance behaviour, an indicator of fear, in the presence of people who have negative attitudes towards them, in comparison with unfamiliar individuals and people with whom they have positive interaction, indicating that animals are able to discriminate among people with distinct behaviours.

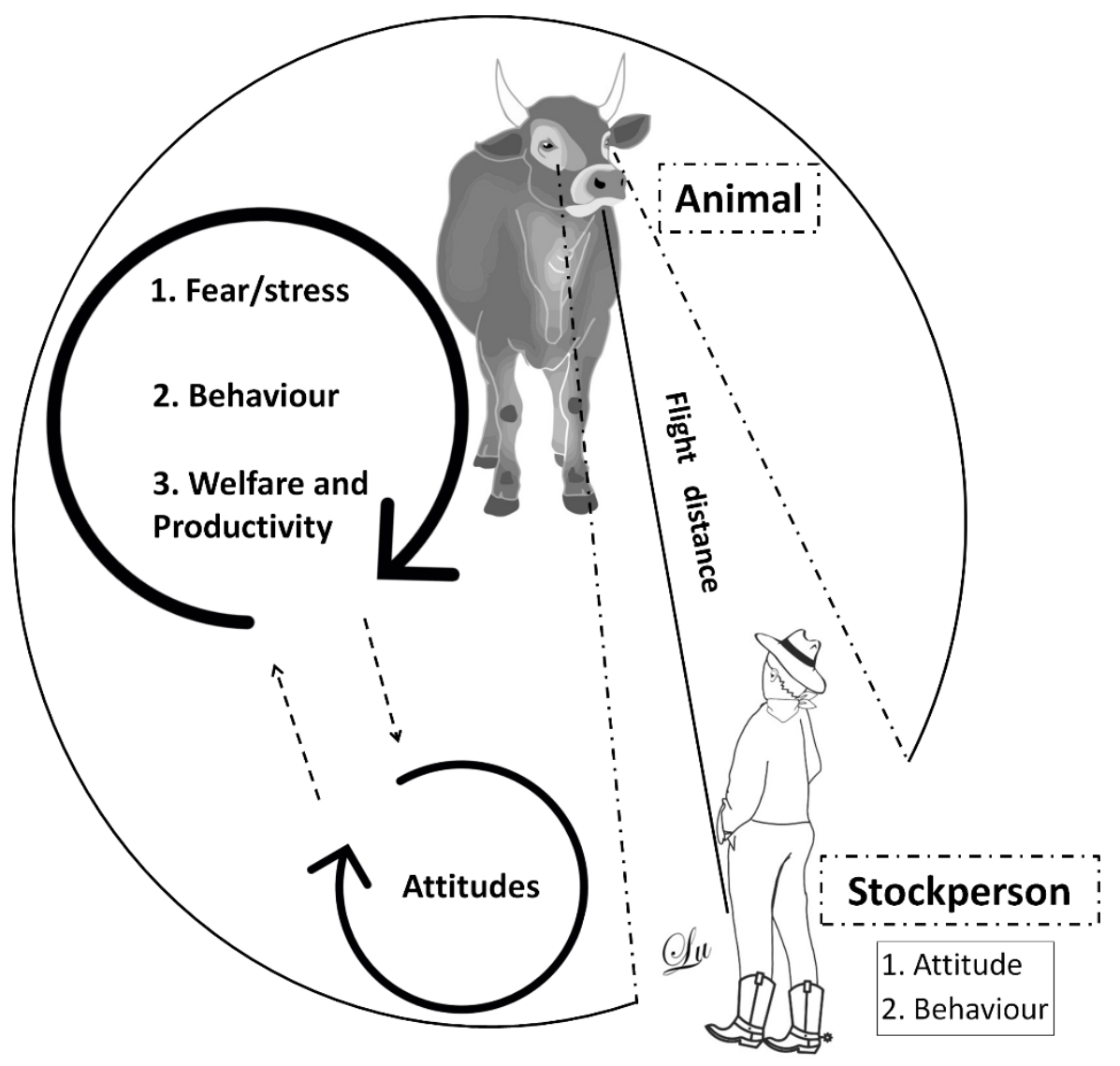

Figure 1 Model of human-animal relationship proposed by Hemsworth and Coleman (1998), adapted from Hemsworth (2003). Most studies on this topic highlight the sequential relations among the attitudes and behaviour of operators towards their animals, fear responses, and the effect of fear on the welfare and productivity of farm animals.

To evaluate general beliefs and attitudes towards animals, and levels of work satisfaction among stockpersons, several questionnaires have been used. For example, in the dairy (Breuer et al 2000) and sheep industries (Napolitano et al 2011). However, some behavioural tests are difficult to interpret, for example, human approaches to animals can be 
perceived as threatening, but the fear the animals feel may induce flight or a freezing reaction (Bourguet et al 2015). Furthermore, activities like feeding reduce the possibility to flee so may be inhibited. The response of the animals may also vary as a function of social rank, the gregarious nature of the animals (Carbajal and Orihuela 2010) and the inter-individual distances that they keep within the group (Boissy and Le Neindre 1997). Many responses are species-dependent and goats (Mattiello et al 2010) are usually considered more curious than sheep because of the exploratory behaviour they often manifest towards people.

It is also important to evaluate animals' reactions during handling procedures (Napolitano et al 2013) because tests that consider this factor may be used to select animals less afraid of humans and, therefore, easier to manage (Windschnurer et al 2009). Animals raised in semi-natural conditions tend to show less interest in humans, perhaps related to the fact that their only contact with them occurs when they are captured in the field and separated from their mother or herd (Rochais et al 2014).

Farm animals are more likely to approach stationary persons than persons actively moving toward them, and humans in squatting position more than those in standing position (Hemsworth et al 1986b; Lyons et al 1988). Farm animal species can also recognize individual humans and are more likely to approach those who treat them well than those who act in an aggressive way. Similarly, the location of prior positive or negative handling experiences can determine how animals approach or avoid the same person in two different places if that person treated them differently in each place (Rushen et al 1999a). Several behavioural tests have been used to assess fearfulness towards humans, as reviewed by Waiblinger et al (2006).

The stockpersons' attitudes towards farm animals can be measured by the animal responses to humans in standardized test situations like the reactivity to an approaching human (Muns et al 2015; Brajon et al 2015) and the avoidance distance test (Edwards et al 2010).

Studies on cattle, poultry and pigs have suggested that the test of reactivity to an approaching moving human, based on the avoidance responses of the animals, reflects the HAR (Waiblinger et al 2006). The human approach test, assesses fear of humans, offering also the possibility to measure the social relationship with humans, the management quality and the extent of individual differences (Waiblinger et al 2006). The WQ protocols rely on human approach tests. A human approach test is also included in the AWIN protocols for horses and sheep (AWIN 2015ab), whereas the AWIN protocol for goats relies on a stationary human test (AWIN, $2015 \mathrm{c}$ ). In cattle, the test of reactivity to a stationary human seems to be less relevant, because it is based on animal approach behaviour towards humans and reflects not just reactivity to humans but a mix of motivations depending on the context of the test (de Passille and Rushen 2005). Conversely, this type of test seems more appropriate for goats, which are generally more exploratory than other farm animals.

The response of sows in stalls to approaching hand contact and the response of free-moving sows in groups to approach by an observer, had been validated by Scott et al (2009) for on-farm welfare assessment in different housing systems. However, according to Powell et al (2016), it should be noted that the human approaching touch is a valid measure of fear to humans in experimental settings, but impractical for on-farm use due to the need for animals to be individually tested in a purpose-built test arena.

The Stationary Person Test, the Avoidance Distance Test and the Touch Test had been validated to effectively measure the human-hen relationship in non-caged systems (Graml et al 2008a). It is worth noting that a complex test including stationary and moving elements has also been validated for birds (Raubek et al 2007). The Avoidance Distance Test has also been recommended by Windschnurer et al (2008) for on-farm welfare assessment for dairy cows. However, some inconsistencies in dairy calves' responses had also been observed (Meagher et al 2016).

Other means to assess the HAR are: (i) use an interview about stockperson practices (Kling-Eveillard et al 2017); (ii) observing stockpersons during common (Ellingsen et al 2014; Rueda et al 2015) or less common handling events (Destrez et al 2018); (iii) assess farmers' attitudes through a questionnaire (Bertenshaw and Rowlinson 2009; Hemsworth et al 2000; Fukasawa et al 2017); or (iv) use video-recording (Johansson et al 2015). However, according to Spoolder (2007), it is more relevant to assess the quality of the HAR directly by looking at farmers' attitudes and handling practices than by assessing fear of humans.

Regardless of the test used, there are some confounding factors that might be considered when interpreting the results. The nature of human contact can significantly modulate how farm animals perceive humans, affecting their behavioural responses (for a review, see Boivin et al 2003; Waiblinger et al 2006; Adler et al 2019).

\section{Effects on productivity and welfare}

The nature of HAR matters as it will modulate not only the welfare of the animal, including its health, but also productivity and product quality (Hemsworth et al 2009; Tallet et al 2018). Research on HAR and animal production has been mainly focused on its effect on stress, productivity and meat quality (Hemsworth 2003; Hemsworth et al 2009; Zulkifli et al 2013).

\section{Negative effects}

Negative handling such as shouting and hitting, leads to poor animal welfare, including fear, acute and chronic stress 
(Hemsworth et al 2000). Fear responses towards humans may affect the productivity (Rushen et al 1999ab), health and stress physiology of farm animals (Hemsworth et al 2000; Hemsworth 2009; Hemsworth and Coleman 2011); as in pigs (Hemsworth 2008; Hemsworth and Coleman 2011; Probst et al 2013), hens (Barnett et al 1994; Graml et al 2008b; Edwards et al 2010), and dairy cows (Lürzel et al 2015; Ivemeyer et al 2018; Adler et al 2019).

\section{In Pigs}

Poor handling results in high levels of fearfulness (Hemsworth and Barnett 1991). Negative behaviours displayed by the stockperson (e.g. slapping, hitting and kicking) are strongly associated with a high level of fear in pigs (Hemsworth et al 1989a).

Stressful, human handling affects pig weight gains negatively (Gonyou et al 1986; Hemsworth and Barnett 1991). Hemsworth et al (1981) subjected gilts to either pleasant or unpleasant human contact for three 2-min periods/week, from 11 to 22 weeks of age. The authors noted that the juvenile females with the pleasant handling treatment had higher weigh gain than those with other treatments.

Lensink et al (2009a), observed that the fear response to humans of nulliparous sows was linked with their behaviour towards humans and nervousness around first farrowing, and these negative interactions were mostly related with prophylactic and therapeutic procedures (Lensink et al 2009b).

Unpleasant physical contact with humans reduced testicle size and delayed coordinated mating response in boars, and reduced pregnancy rate in sows, when compared with those receiving positive human handling (Hemsworth et al 1986c).

A study undertaken by Sommavilla et al (2011) showed that loud tones, making threatening postures and forcing piglets in the creep area during the suckling period were perceived as aversive, and increased the withdrawal response of piglets to human approach on the day of weaning compared with piglets that received a neutral treatment. Similarly, Brajon et al (2015) showed that rough handling, even without physical stress, was enough to activate a fear response in weaned piglets.

\section{In Poultry}

High fear of humans is associated with reduced egg production, growth, feed efficiency, product quality and sexual activity whilst increasing aggression, handling difficulties and immunosuppression (Barnett et al 1993; 1994; Gross and Siegel 1982; Jones 1996).

Visual or physical contact with humans can elicit behavioural inhibition, withdrawal panic and violent escape reactions in chickens (Jones 1996), often with associated injury as well as adrenal responses. Fear reactions, like panic or violent escape attempts, not only waste energy and thereby impose a metabolic cost, but they can also result in injury or even death when the birds run into obstacles or pile on top of each other (Waiblinger et al 2006).

In Cattle and Buffaloes

Poor HAR is associated with reduced milk production by cows (Seabrook 1984; Waiblinger et al 2002). Aversion to shouts has been reported (Waynert et al 1999; Pajor et al 2000). Ellingsen et al (2014) observed that stockpersons with a nervous handling style or who were dominant and aggressive, induced a negative mood in more cows. des Roches et al (2016) confirmed that cows' fear of people is linked to negative attitudes displayed by caretakers toward cows and is reduced in farms where several caretakers are present. Likewise, cattle show more intense fear responses to humans in larger farms with higher levels of mechanization, due to the lower frequency of contact with the stockperson (Mattiello et al 2009). Rushen et al (1999b) reported that the presence of an aversive stockperson at milking, who had previously hit or occasionally used a battery-operated prodder over a 5-day period, led cows to increase their residual milk. Similarly, Munksgaard et al (1997) observed that, following the aversive treatment of striking the cow forcefully with an open hand, cows urinated and defecated more frequently. In addition, Arias and Špinka (2005) found that in farms with more neurotic stockpersons, the cows had lower milk yields per standardized lactation and higher veterinary costs. Hemsworth et al (2000) found that the use of negative interactions with cattle by stockpersons was not only negatively correlated with milk yield, but also with percent protein and fat, and positively correlated with milk cortisol concentration.

There is evidence that excitable temperament in stockpersons increases the risk of aggressive handling and tends to decrease labour efficiency, for example, by increasing the time needed to perform artificial insemination and reducing cows' body hygiene (Rueda et al 2015). Heifers that faced negative handling and were more reactive during handling had higher dirtiness scores and these were associated with lower pregnancy rates (Ceballos et al 2018). Furthermore, cows that required more handling time in the corral, produced fewer viable embryos (Macedo et al 2011). Aggressive and mild-escape behaviours during head-lock restraint had negative effects on reproductive performance of dairy heifers (Kasimanickam et al 2018). Moreover, fear of humans may also decrease meat quality, such as tenderness (Ferguson and Warner 2008; Probst et al 2012).

In dairy buffaloes the number of negative interactions performed by stock-people was positively correlated with the number of kicks by buffaloes during milking and with the 
number of exogenous oxytocin injections used to induce milk let-down (Napolitano et al 2019). These results support the hypothesis that the behaviour of stock-people and buffaloes are related and indicate room for improvement following appropriate stock-people training programmes.

\section{Positive effects}

In contrast, a positive relationship is notably characterized by absence of fear reactions to humans and animals that are easier to handle (Waiblinger et al 2006). Positive interactions such as pats, gentle slaps or talking to the animals showed positive effects reducing fear and human avoidance. Also, among the interactions with humans that can be perceived as positive, food provision is an efficient way of attracting animals (Jago et al 1999; Tallet et al 2005; Graml et al 2008a). Stockpersons with positive attitudes towards animals often have animals with increased productivity (Rushen and de Passillé 2015).

In Pigs

Human-animal interactions as short as 4 $\mathrm{h} /$ sow/reproductive cycle, may influence both the performance and welfare of the animals (Prunier and Tallet 2015). Janczak et al (2003) found that sows showing less fear of humans had higher reproductive success and more adaptive maternal behaviour.

According to Hemsworth et al (1994), human recognition can happen in situations of intensive handling. Intact males, that are commonly raised in stable groups in some countries, when they were positively handled were more socially active, both in their groups and with an unfamiliar human (Tallet et al 2013).

In Poultry

Handling studies on poultry show that regular positive gentle handling can enhance growth performance, feed efficiency (Gross and Siegel 1982; Zulkifli and Siti Nor Azah 2004), egg production (Barnett et al., 1994), disease resistance to infection, antibody protection (Graml et al 2008a; Edwards et al 2010; Al-Aqil et al 2013) and first-week survival (Cransberg et al 2000).

In adult laying hens, reduction in fear of humans and a decrease in plasma corticosterone concentration were shown following additional handling, consisting of walking, talking, feeding and touching single birds (Barnett et al 1994; Graml et al 2008a). Similarly, Edwards et al (2010) showed for laying hens that $12 \mathrm{~min} /$ day of visual contact with humans during rearing resulted in reduced avoidance behaviour of humans during adulthood and there was a trend for hens receiving positive handling to have a lower corticosterone response to human contact than those receiving negative handling. Visible human presence associated with predictable approach, human voice, slow movements and gentle handling for weighing, were effective in inducing habituation to humans in laying hens (Bertin et al 2019).

Al-Aqil et al (2013) subjected broiler chicks to a pleasant physical contact $30 \mathrm{sec} /$ day from 1 to 28 days of age and found that those chickens had lower heterophil/lymphocyte ratios (h/l) and plasma corticosterone levels than their neglected counterparts following road transportation. Zulkifli et al (2002) suggested that allowing broiler chickens to see the experimenter for 10 min twice daily from 0 to 3 weeks of age, with no attempt to initiate tactile interaction with the birds, was sufficient to alleviate fear and stress reactions to handling and crating, and improve their antibody response. In a study conducted by Zulkifli et al (2004), some chicks were randomly caught, picked up and stroked gently for 10 min twice daily, and other chicks were picked up individually and stroked gently for $30 \mathrm{sec}$ once daily in their home pen. While positive visual contact had no effect on performance, birds that were handled pleasantly had improved body weight and feed conversion ratios.

\section{In Cattle and Buffaloes}

Hemsworth et al (1989b) reported that the stockperson's presence and positive handling during calving of heifers led to faster approach to an experimenter in a test situation, lower cortisol concentrations, and less stepping and kicking responses during milking in the first weeks of lactation than heifers that calved without human presence. According to Ellingsen et al (2014), stockpersons who handle their calves patiently, pet them and calmly talk to them during handling, induce in their animals' higher levels of positive mood. The influence of gentle interactions on weight gain in group-housed dairy calves has been studied by Lürzel et al (2015). Gentle stroking in dairy cattle has been shown to reduce heart rate increased during a veterinary procedure (Schmied et al 2010). In addition, in beef cattle, gentle touching at an early age seems to reduce the cortisol release at slaughter (Probst et al 2012).

The HAR is also relevant for udder health. Ivemeyer et al $(2011 ; 2018)$ found that positive behaviour of stockpersons during milking was associated with lower somatic cell counts and with lower prevalence of mastitic quarters.

As also observed in cattle, in dairy buffaloes the number of positive interactions performed by stock-people was positively correlated with milk production (Napolitano et al 2019).

\section{Factors affecting the quality of HAR}

At least three aspects are important in affecting the quality of HAR: 1) a genetic influence indicating the relevance of genetic selection, 2) the development of husbandry practices that improve animal's perception of humans, 
sometimes by habituation (Boissy et al 2002; Faure et al 2003) and 3) early positive human contact, that could influence future emotional experiences in animals to stressors when in the presence of humans.

\section{Genetic influences}

Genetic dispositions contribute to personality differences, partly explaining differences in HAR within a herd or between breeds (Andersen et al 2006). Stockpersons deliberately or accidentally select tame animals for breeding stock because they are easier to handle and manage (Price and Orihuela 2010), and tameness heritability has been estimated to be about 22 (Le Neindre et al 1995) to $38 \%$ (Hemsworth et al 1990).

Lankin (1997) studied the behavior of 11 breeds of sheep and concluded that breeds subjected to intensive selection for commercial purposes were tamer toward humans than breeds which had not been subjected to such selection. Also, Lyons et al (1988) examined the tameness of dairy goats toward humans, both within and between twin sets. One sibling of each twin set was reared by the mother while the other was hand reared. The tameness scores of the hand-reared goats were better than for their dam-reared twin.

\section{Habituation}

In habituation, the animal's fear of humans is gradually reduced by repeated exposures in a neutral context, when a person's presence has no obvious reinforcement properties (Price and Orihuela 2010). For example, Jones et al (1993) found that domestic chicks showed decreased avoidance of humans following twice daily exposures to humans.

Similarly, Prado et al (2001) found that bucks raised under semi-intensive conditions but habituated to the human presence, became easier to train for semen collection using an artificial vagina, than bucks raised under extensive conditions, with little or no human presence.

\section{Early contact}

Positive human animal contacts and handling can efficiently affect the quality of the relationship when the interactions are conducted at a young age. Indeed, Le Neindre et al (1996) found that young range-reared cattle increased their tolerance of human presence if exposed to human handling just after weaning.

Early tactile stimulation influences the postnatal development of pigs (Tanida et al 1995; de Oliveira et al 2015). Early gentle contact with humans enhances approach behaviour to human beings (Hemsworth et al 1986a). Piglets whose back was stroked by humans for $2 \mathrm{~min}$ from 5 to 35 days of age, were less fearful in a novel environment and less fearful of being handled by people (de Oliveira et al 2015). Muns et al (2015) found that positive contact reduced the duration of escape behaviour of piglets to tail-docking on day 15. Furthermore, according to Büttner et al (2018) positive HAR (e.g. calm speech, petting, food provision), carried out 3 times/week by one person for $15 \mathrm{~min}$ in each pen during the rearing period, can reduce the occurrence of tail-biting in weaned piglets.

Several authors have showed that previous positive handling may improve ease of handling later in life in several species. For example, favoring ease of handling while loading calves for transport (Lensink et al 2001), and reducing fear related reactions at the abattoir in beef cattle, which can be the reason for improved tenderness of meat (Probst et al., 2012); reducing vocalizations in unfamiliar environments (Boivin et al 2000; Tallet et al 2008), heart rate, cortisol concentration (Tosi and Hemsworh 2002) and flight distance in lambs (Markowitz et al 1998); and reducing kicking in dairy cows during rectal palpation (Waiblinger et al 2004) and fear of humans in chickens (Jones and Waddington 1993).

Domestic horse foals showed less fear of humans if they had contact with humans during their first 5 days of age, even if they were just observing their mothers being fed by hand and brushed (Hausberger et al 2008) or when exposed to motionless humans (Henry et al 2006).

There is some evidence that mothers may be an important social model, modulating or buffering the behavioral and physiological responses associated with the development of HAR in their young (Waiblinger 2017; 2019).

\section{Final Considerations}

We conclude that even with improved precision farming and automation: a) a good HAR is still fundamental to improve farm animal welfare with associated health and production benefits and $b$ ) with the numerous tests assessing fear of humans, many are not commercially applicable.

\section{Conflict of Interest}

The authors declare that there are no conflicts of interest with this work.

\section{References}

Adler F, Christley R, Campe A (2019) Examining farmers' personalities and attitudes as possible risk factors for dairy cattle health, welfare, productivity, and farm management: A systematic scoping review. Journal of Dairy Science 102:3805-3824.

Al-Aqil A, Zulkifli I, Hair Bejo M, Sazili AQ, Rajion MA, Somchit MN (2013) Changes in heat shock protein 70, blood parameters and fear-related behavior in broiler chickens as affected by pleasant and unpleasant human contact. Poultry Science 92:33-40.

Andersen IL, Berg S, Bøe KE, Edwards SA (2006) Positive handling in late pregnancy and the consequences for maternal behavior and production in sows. Applied Animal Behaviour Science 99:64-76. 
Arias JLP, Špinka M (2005) Associations of stockpersons' personalities and attitudes with performance of dairy cattle herds. Czech Journal of Animal Science 50: 226-34.

AWIN (2015a) AWIN Welfare Assessment Protocol for Sheep. doi:10.13130/AWIN_sheep_2015.

AWIN (2015b) AWIN Welfare Assessment Protocol for Horses. doi: 10.13130/awin_horses_2015.

AWIN (2015c) AWIN Welfare Assessment Protocol for Goats. doi:10.13130/AWIN_goats_2015.

Barnett JL, Hemsworth PH, Jones RB (1993) Behavioral responses of commercially farmed laying hens to humans: evidence of stimulus generalization. Applied Animal Behaviour Science 37:139-146.

Barnett JL, Hemsworth PH, Hennessy DP, McCallum TH, Newmann EA (1994) The effects of modifying the amount of human contact on behavioral, physiological and production responses of laying hens. Applied Animal Behaviour Science 41:87-100.

Bertenshaw C, Rowlinson P (2009) Exploring stock managers' perceptions of the human-animal relationship on dairy farms and an association with milk production. Anthrozoos 22:59-69.

Bertin A, Mocz F, Calandreau L, Palme R, Lumineau S, Darmaillacq S, Houdelier C (2019) Human behavior at the origin of maternal effects on offspring behavior in laying hens (Gallus gallus domesticus). Physiology Behaviour 201:175-183.

Boissy A, Le Neindre P (1997) Behavioral, cardiac and cortisol responses to brief peer separation and reunion in cattle. Physiology Behavior 61:693-699.

Boissy A, Fisher A, Bouix J, Boivin X, Le Neindre P (2002, August) Genetics of fear and fearfulness in domestic herbivores. Paper presented at the Seventh World Congress on Genetics Applied to Livestock Production, Montpellier, FR.

Boivin S, Tournadre H, Le Neindre P (2000) Hand-feeding and gentling influence early weaned lambs' attachment responses to their stock person. Journal of Animal Science 78:879-884.

Boivin X, Lensink BJ, Tallet C, Veissier I (2003) Stockmanship and farm animal welfare. Animal Welfare 12:479-92.

Bourguet C, Deiss V, Boissy A, Terlouw EMC (2015) Young Blond d'Aquitaine, Angus and Limousin bulls differ in emotional reactivity: Relationships with animal traits, stress reactions at slaughter and post-mortem muscle metabolism. Applied Animal Behaviour Science 164:41-55.

Brajon S, Laforest JP, Bergeron R, Tallet C, Hötzel MJ, Devillers N (2015) Persistency of the piglet's reactivity to the handler following a previous positive or negative experience. Applied Animal Behaviour Science 162:9-19.

Breuer K, Hemsworth PH, Barnett JL, Matthews LR, Coleman GL (2000) Behavioral response to humans and the productivity of commercial dairy cows. Applied Animal Behaviour Science 66:27388 .

Büttner K, Czycholl I, Basler H, Krieter J (2018) Effects of an intensified human-animal interaction on tail biting in pigs during the rearing period. Journal of Agricultural Science 156:1039-46.

Carbajal S, Orihuela A (2010) Minimal number of conspecifics needed to minimize the stress response of isolated mature ewes. Journal of Applied Animal Welfare Science 4:249-255.

Caroprese M, Napolitano F, Mattiello S, Fthenakis GC, Ribó O, Sevi A (2016) On-farm welfare monitoring of small ruminants. Small Ruminant Research 135:20-25.
Ceballos MC, Sant'Anna AC, Góis KCR, Ferraudo AS, Negrao JA, da Costa MJRP (2018) Investigating the relationship between human-animal interactions, reactivity, stress response and reproductive performance in Nellore heifers. Livestock Science 217:65-75.

Claxton AM (2011) The potential of the human-animal relationship as an environmental enrichment for the welfare of zoo-housed animals. Applied Animal Behaviour Science 133:1-10.

Cransberg PH, Hemsworth PH, Coleman GJ (2000) Human factors affecting the behavior and productivity of commercial broiler chickens. British Poultry Science 41:272-79.

de Oliveira D, Paranhos da Costa MJR, Zupan M, Rehn T, Keeling LJ (2015) Early human handling in non-weaned piglets: Effects on behavior and body weight. Applied Animal Behaviour Science 164:56-63.

de Passillé AM, Rushen J (2005) Can we measure human-animal interactions in on-farm animal welfare assessment? Some unresolved issues. Applied Animal Behaviour Science 92:193-209.

des Roches AB, Veisser I, Boivin X, Gilot-Fromont E, Mounier L (2016) A prospective exploration of farm, farmer, and animal characteristics in human-animal relationships: An epidemiological survey. Journal of Dairy Science 99:5573-85.

Destrez A, Haslin E, Boivin X (2018) What stockperson behavior during weighing reveals about the relationship between humans and suckling beef cattle: A preliminary study. Applied Animal Behavior Science 209:8-13.

Edwards LE, Botheras NA, Coleman GJ, Hemsworth PH (2010) Behavioral and physiological responses of laying hens to humans. Animal Production Science 50:557-59.

Ellingsen K, Coleman GJ, Lund V, Mejdell CM (2014) Using qualitative behavior assessment to explore the link between stockperson behavior and dairy calf behavior. Applied Animal Behavior Science 153:10-17.

Faure JM, Bessei W, Jones RB (2003) Direct selection for improvement of animal well-being. In: Muir WM, Aggrey SE (Eds.), Poultry Genetics, Breeding and Biotechnology (pp. 221245). Wallingford, UK: CABI Publishing.

Ferguson DM, Warner RD (2008) Have we underestimated the impact of pre-slaughter stress on meat quality in ruminants? Meat Science 80:12-19.

Fukasawa M, Kawahata M, Higashiyama Y, Komatsu T (2017) Relationship between the stockperson's attitudes and dairy productivity in Japan. Animal Science Journal 88:394-400.

Gonyou HW, Hemsworth PH, Barnett JL (1986) Effects of frequent interactions with humans on growing pigs. Applied Animal Behaviour Science 16:269-78.

Graml C, Waiblinger S, Niebuhr K (2008a) Validation of tests for onfarm assessment of the hen-human relationship in non-cage systems. Applied Animal Behaviour Science 111:301-310.

Graml C, Niebuhr K, Waiblinger S (2008b) Reaction of laying hens to humans in the home or a novel environment. Applied Animal Behaviour Science 113:98-109.

Gross WB, Siegel PB (1982) Socialization as a factor in resistance to disease, feed efficiency and response to antigen in chickens. American Journal of Veterinary Research 43:2010-12.

Hausberger M, Roche H, Henry S, Visser EK (2008) A review of the human-horse relationship. Applied Animal Behaviour Science 109:1-24. 
Hemsworth PH, Barnett JL, Hansen C (1981) The influence of handling by humans on the behavior, growth and corticosteroids in the juvenile female pig. Hormones and Behavior 15:396-403.

Hemsworth PH, Barnett JL, Hansen C, Gonyou HW (1986a) The influence of early contact with humans on subsequent behavioral response of pigs to humans. Applied Animal Behaviour Science 15:55-63.

Hemsworth PH, Gonyou HW, Dziuk PJ (1986b) Human communication with pigs: the behavioral response of pigs to specific human signals. Applied Animal Behaviour Science 15:45-54.

Hemsworth PH, Barnett JL, Hansen C (1986c) The influence of handling by humans on the behavior, reproduction and corticosteroids of male and female pigs. Applied Animal Behaviour Science 15:303-14.

Hemsworth PH, Barnett JL, Hansen C (1987) The influence of inconsistent handling by humans on the behavior, growth and corticosteroids of young pigs. Applied Animal Behaviour Science $17: 245-52$.

Hemsworth PH, Barnett JL, Coleman GJ, Hansen C (1989b) A study of the relationships between the attitudinal and behavioral profiles of stockpersons and the level of fear of human and reproductive performance of commercial pigs. Applied Animal Behaviour Science 23:301-14.

Hemsworth PH, Barnett JL, Tilbrook AJ, Hansen C (1989a) The effects of handling by humans at calving and during milking on the behavior and milk cortisol concentrations of primiparous dairy cows. Applied Animal Behaviour Science 22:313-26.

Hemsworth PH, Barnett JL, Treacy D, Madgwick P (1990) The heritability of the trait fear of humans and the association between this trait and subsequent reproductive performance of gilts. Applied Animal Behaviour Science 25:85-95.

Hemsworth PH, Barnett JL (1991) The effects of aversively handling pigs, either individually or in groups, on their behavior, growth and corticosteroids. Applied Animal Behaviour Science 30:61-72.

Hemsworth PH, Coleman GJ, Cox M, Barnett JL (1994) Stimulus generalization: the inability of piglets to discriminate between humans on the basis of their previous handling experience. Applied Animal Behaviour Science 40:129-42.

Hemsworth PH, Coleman GJ (1998) Human-Livestock Interactions: The Stockperson and the Productivity and Welfare of Intensively Farmed Animals. Wallingford, UK: CAB International.

Hemsworth PH, Coleman GJ, Barnett JL, Borg S (2000) Relationships between human-animal interactions and productivity of commercial dairy cows. Journal of Animal Science 78:2821-31.

Hemsworth PH (2003) Human-animal interactions in livestock production. Applied Animal Behaviour Science 81:185-98.

Hemsworth PH (2008) Human-pig relationships. In: Faucitano L, Schaefer AL (Eds.), Welfare of Pigs from Birth to Slaughter (pp. 271288). Wageningen, NL: Academic Publishers.

Hemsworth PH (2009) Impact of human-animal interactions on the health, productivity and welfare of farm animals. In: Aland A, Madec F (Eds.), Sustainable Animal Production: The Challenges and Potential Developments for Professional Farming (pp. 57-68), Wageningen, NL: Academic Publishers.

Hemsworth PH, Barnett JL, Coleman GJ (2009) The integration of human-animal relations into animal welfare monitoring schemes. Animal Welfare 18:335-45.
Hemsworth PH, Coleman GJ (2011) Human-animal interactions and animal productivity and welfare. In: Human-livestock interactions. The Stockperson and the Productivity of Intensively Farmed Animals (pp. 47-83). Oxford, UK: CAB International.

Henry S, Richard-Yris MA, Hausberger M (2006) Influence of various early human-foal interferences on subsequent human-foal relationship. Developmental Psychobiology 48:712-718.

Ivemeyer S, Knierim U, Waiblinger S (2011) Effect of human-animal relationship and management on udder health in Swiss dairy herds. Journal of Dairy Science 94:5890-5902.

Ivemeyer S, Simantke C, Ebinghaus A, Poulsen PH, Sorensen JT, Rousing T, Knierim U (2018) Herd-level associations between human-animal relationship, management, fecal cortisol metabolites, and udder health of organic dairy cows. Journal of Dairy Science 101:7361-74.

Jago JG, Krohn CC, Matthews LR (1999) The influence of feeding and handling on the development of the human-animal interactions in young cattle. Applied Animal Behaviour Science 62:137-51.

Janczak AM, Pedersen LJ, Rydhmer L, Bakken M (2003) Relation between early fear- and anxiety-related behavior and maternal ability in sows. Applied Animal Behaviour Science 82:121-35.

Johansson A, Blokhuis HJ, Berckmans D, Butterworth A (2015) Development of an automatic method to assess the human-animal relationship in broilers at flock level. Paper presented at the Seventh European Conference on Precision Livestock Farming, Milan, ITL.

Jones RB, Waddington D (1993) Attenuation of the domestic chick's fear of human beings via regular handling: in search of a sensitive period. Applied Animal Behaviour Science 36:185-195.

Jones RB, Hemsworth PH, Barnett JL (1993, September) Fear of humans and performance in commercial broiler flocks. In: Savory CJ, Hughes BO (Eds.), Proceedings of the $4^{\text {th }}$ UFAW European Symposium on Poultry Welfare, Potters Bar, UK.

Jones RB (1996) Fear and adaptability in poultry: insights, implications and imperatives. World Poultry Science Journal 52:13374.

Kasimanickam VR, Staker C, Williams HM, Kastelic JP, Kasimanickam R (2018) Aggressive attempted escape behavior during head-lock restraint reduced reproductive performances in Holstein heifers. Theriogenology 121:147-152.

Kling-Eveillard F, Hostiou N, Ganis E, Philibert A (2017, September) The effects of PLF on human-animal relationships on farms. Paper presented at the 8th European Conference on Precision Livestock Farming, Nantes, FR.

Lankin V (1997) Factors of diversity of domestic behavior in sheep. Genetics Selection Evolution 29:73-92.

Le Neindre P, Boivin X, Boissy A (1996) Handling of extensively kept animals. Applied Animal Behaviour Science 49:73-81.

Le Neindre P, Trillat C, Sapa J, Ménissier F, Bonnet JN, Chupin J (1995) Individual differences in docility in Limousin cattle. Journal of Animal Science 73:2249-2253.

Lensink BJ, Leruste H, Le Roux T, Bizeray-Filoche D (2009a) Relationship between the behavior of sows at 6 months old and the behavior and performance at farrowing. Animal 3:128-134.

Lensink BJ, Leruste H, de Bretagne T, Bizeray-Filoche D (2009b) Sow behavior towards humans during standard management procedures and their relationship to piglet survival. Applied Animal Behaviour Science 119:151-157. 
Lürzel S, Münsch C, Windschnurer I, Futschik A, Palme R, Waiblinger S (2015) The influence of gentle interactions on avoidance distance towards humans, weight gain and physiological parameters in group-housed dairy calves. Applied Animal Behaviour Science 172:9-16.

Lyons DM, Price EO, Moberg GP (1988) Individual differences in temperament of domestic dairy goats: constancy and change. Animal Behaviour 36:1323-1333.

Macedo GG, Zúccari CE, de Abreu UG, Negrão JA, da Costa e Silva EV (2011) Human-animal interaction, stress, and embryo production in Bos indicus embryo donors under tropical conditions. Tropical Animal Health and Production 43:1175-1182.

Markowitz TM, Dally MR, Gursky K, Price EO (1998) Early handling increases lamb affinity for humans. Animal Behaviour 55:573-587.

Mattiello S, Klotz C, Baroli D, Minero M, Ferrente V, Canali E (2009) Welfare problems in alpine cattle farms in Alto Adige (Eastern Italian Alps). Italian Journal of Animal Science 8:628-30.

Mattiello S, Battini M, Andreoli E, Minero M, Barbieri S, Canali E (2010) Avoidance distance test in goats: A comparison with its application in cows. Small Ruminant Research 91:215-218.

Meagher RK, von Keyserlingk MAG, Atkinson D, Weary DM (2016) Inconsistency in dairy calves' responses to tests of fearfulness. Applied Animal Behaviour Science 185:15-22.

Munksgaard L, de Passillé AM, Rushen J, Thodberg K, Jensen MB (1997) Discrimination of people by dairy cows based on handling. Journal of Dairy Science 80:1106-1112.

Muns R, Rault JL, Hemsworth P (2015) Positive human contact on the first day of life alters the piglet's behavioral response to humans and husbandry practices. Physiology Behavior 151:162-167.

Napolitano F, De Rosa G, Girolami A, Scavone M, Braghieri A (2011) Avoidance distance in sheep: Test-retest reliability and relationship with stockmen attitude. Small Ruminant Research 99:81-86.

Napolitano F, Pacelli C, Grasso F, Braghieri A, De Rosa G (2013) The behavior and welfare of buffaloes (Bubalus bubalis) in modern dairy enterprises. Animal 7:1704-1713.

Napolitano F, Serrapica M, Braghieri A, Masucci F, Sabia E, De Rosa G (2019) Human-animal interactions in dairy buffalo farms. Animals 9:246.

Pajor EA, Rushen J, de Passillé AMB (2000). Aversion learning techniques to evaluate dairy cattle handling practices. Applied Animal Behaviour Science 69:89-102.

Powell C, Hemsworth LM, Rice M, Hemsworth PH (2016) Comparison of methods to assess fear of humans in commercial breeding gilts and sows. Applied Animal Behaviour Science 181:7075 .

Prado VM, Orihuela A, Lozano TS, Pérez-León MI (2001) Effect of the breeding system (extensive vs. semi-intensive) of male goat, on obtaining semen via artificial vagina. Veterinaria México 32:297299.

Price EO, Orihuela A (2010) Conducta Animal Aplicada al Cuidado y Producción Pecuaria. (Animal Behavior Applied to Livestock Care and Production). México, D.F.: Editorial Trillas.

Probst JK, Neff AS, Leiber F, Kreuzer M, Hillmann E (2012) Gentle touching in early life reduces avoidance distance and slaughter stress in beef cattle. Applied Animal Behaviour Science 139:42-49.
Probst JK, Hillmann E, Leiber F, Kreuzer M, Spengler NA (2013) Influence of gentle touching applied few weeks before slaughter on avoidance distance and slaughter stress in finishing cattle. Applied Animal Behaviour Science 144:14-21.

Prunier A, Tallet C (2015) Chapter 12. Endocrine and behavioural responses of sows to human interactions and consequences on reproductive performance. In: Farmer C (Ed.), The Gestating and Lactating Sow (279-296). Wageningen, NL: Academic Publishers.

Raubek J, Niebuhr K, Waiblinger S (2007) Development of on-farm methods to assess the animal-human relationship in laying hens kept in non-cage systems. Animal Welfare 16:173-175.

Rochais C, Henry S, Sankey C, Nassur F, Goracka-Bruzda A, Hausberger M (2014) Visual attention, an indicator of human-animal relationships? A study of domestic horses (Equus caballus). Frontiers in Psychology 5:108.

Rueda PM, Sant'Anna AC, Valente TS, da Costa MJRP (2015) Impact of the temperament of Nellore cows on the quality of handling and pregnancy rates in fixed-time artificial insemination. Livestock Science 177:189-95.

Rushen J, Taylor AA, de Passillé AM (1999a). Domestic animals' fear of humans and its effect on their welfare. Applied Animal Behaviour Science 65:285-303.

Rushen J, de Passillé AM, Munksgaard L (1999b) Fear of people by cows and effects on milk yield, behaviour and heart rate at milking. Journal of Dairy Science 82:720-27.

Rushen J, de Passillé AM (2015) The importance of good stockmanship and its benefits to animals. In: Grandin T (Ed.), Improving Animal Welfare: A Practical Approach (pp. 125-138), Wallingford, UK: CAB International.

Sankey C, Richard-Yris MA, Leroy H, Henry S, Hausberger M (2010) Positive interactions lead to lasting positive memories in horses, Equus caballus. Animal Behavior 79:869-875.

Schmied C, Boivin X, Scala S, Waiblinger S (2010) Effect of previous stroking on reactions to a veterinary procedure behavior and heart rate of dairy cows. Interaction Studies 11:467-81.

Scott K, Laws DM, Courboulay V, Meunier-Salaün MC, Edwards SA (2009) Comparison of methods to assess fear of humans in sows. Applied Animal Behaviour Science 118:36-41.

Seabrook, M. F. (1984). The psychological interaction between the stockman and his animals and its influence on performance of pigs and dairy cows. Veterinary Science, 115, 84-87.

Sommavilla R, Hötzel MJ, Dalla Costa OA (2011) Piglets' weaning behavioral response is influenced by quality of human-animal interactions during suckling. Animal 5:1426-1431.

Spoolder H (2007) Fear of humans. In: Velarde A, Geers R (Eds.), On Farm Monitoring of Pig Welfare (pp. 33-39), Wageningen, NL: Academic Publications.

Tallet C, Veissier I, Boivin X (2005) Human contact and feeding as rewards for the lamb's affinity to their stockperson. Applied Animal Behaviour Science 94:59-73.

Tallet C, Veissier I, Boivin X (2008) Temporal association between food distribution and human caregiver presence and the development of affinity to humans in lambs. Developmental Psychobiology $50: 147-159$

Tallet C, Brilloüet A, Meunier-Salaün MC, Paulmier V, Guérin C, Prunier A (2013) Effects of neonatal castration on social behavior, human-animal relationship and feeding activity in finishing pigs 
reared in a conventional or an enriched housing. Applied Animal Behaviour Science 145:70-83.

Tallet C, Brajon S, Devillers N, Lensink J (2018) Pig-human interactions: Creating a positive perception of humans to ensure pig welfare. In: Špinka M (Ed.). Advances in Pig Welfare, (pp. 381-398). Amsterdam, NL: Elsevier Science.

Tanida H, Miura A, Tanaka T, Yoshimoto T (1995) Behavioral response to humans in individually handled weaning pigs. Applied Animal Behaviour Science 42:249-59.

Tosi MV, Hemsworth PH (2002) Stockperson-husbandry interactions and animal welfare in the extensive livestock industries. Paper presented at the $36^{\text {th }}$ International Society for Applied Ethology Congress, Wageningen NL.

Waiblinger S, Menke C, Coleman G (2002) The relationship between attitudes, personal characteristics and behavior of stockpeople and subsequent behavior and production of dairy cows. Applied Animal Behaviour Science 79:195-219.

Waiblinger S, Menke C, Korff J, Bucher A (2004) Previous handling and gentle interactions affect behavior and heart rate of dairy cows during a veterinary procedure. Applied Animal Behaviour Science $85,31-42$.

Waiblinger S, Boivin X, Pedersen V, Tosi MV, Janczak AM, Visser EK, Jones RB (2006) Assessing the human-animal relationship in farmed species: a critical review. Applied Animal Behaviour Science 101:185-242.

Waiblinger S (2017) Human-animal relations. In: P. Jensen (Ed.), The Ethology of Domestic Animals: An Introductory Text, (pp. 135146). Wallingford UK: CAB International,

Waiblinger S (2019) Agricultural animals. In: Hosey G and Melfi V (Eds.), Anthrozoology: Human-Animal Interactions in Domesticated and Wild Animals, (pp. 32-58). Oxford, UK: Oxford University Press.

Waynert DF, Stookey JM, Schwartzkopf-Genswein KS, Watts JM, Waltz CS (1999) The response of beef cattle to noise during handling. Applied Animal Behaviour Science 62:27-42.

Welfare Quality® (2009a) Assessment Protocol for Cattle. Welfare Quality ${ }^{\circledR}$ Consortium, Lelystad, The Netherlands.

Welfare Quality ${ }^{\circledR}$ (2009b) Assessment Protocol for Pigs. Welfare Quality ${ }^{\circledR}$ Consortium, Lelystad, The Netherlands.

Welfare Quality (2009c) Assessment Protocol for Poultry. Welfare Quality ${ }^{\circledR}$ Consortium, Lelystad, The Netherlands.

Welp T, Rushen J, Kramer DL, Festa-Bianchet M, de Passillé AM (2004) Vigilance as a measure of fear in dairy cattle. Applied Animal Behaviour Science 87:1-13.

Windschnurer I, Schmied C, Boivin X, Waiblinger S (2008) Reliability and inter-test relationship of tests for on-farm assessment of dairy cows' relationship to humans. Applied Animal Behaviour Science 114:37-53.

Windschnurer I, Boivin X, Waiblinger S (2009) Reliability of an avoidance distance test for the assessment of animals' responsiveness to humans and a preliminary investigation of its association with farmers' attitudes on bull fattening farms. Applied Animal Behaviour Science 117:117-127.

Zulkifli I, Gilbert J, Liew PK, Ginsos J (2002) The effects of regular visual contact with human beings on fear, stress, antibody and growth responses in broiler chickens. Applied Animal Behaviour Science 79:103-112.
Zulkifli I, Siti Nor Azah A (2004) Fear and stress reactions, and the performance of commercial broiler chickens subjected to regular pleasant and unpleasant contacts with human being. Applied Animal Behaviour Science 88:77-87.

Zulkifli I (2013) Review of human-animal interactions and their impact on animal productivity and welfare. Journal of Animal Science and Biotechnology 4:25. 